\title{
Legal Certainty - Protected Values and Partial Objectives: The Case of the Czech Republic ${ }^{1}$
}

\author{
Jana Janderová \\ University of Pardubice, Faculty of Economics and Administration, \\ The Czech Republic \\ jana.janderova@upce.cz \\ https://orcid.org/0000-0002-6425-673X \\ Petra Hubálková \\ University of Pardubice, Faculty of Economics and Administration, \\ The Czech Republic \\ st53678@student.upce.cz
}

Received: 8. 1.2021

Accepted: 30. 3. 2021

\section{ABSTRACT}

Legal certainty is an essential prerequisite for individuals' autonomy, as lack of certainty prevents the planning of future activities and making rational decisions. As other key legal principles, it comprises an axiological quality which influences the interpretation of legal rules and the application of statutory laws. Thus, it should be adhered to by all branches of state power. Its objective is to promote several values that are all important for the protection of human rights: the rule of law, protection of legitimate expectations, general trust in law, prevention of arbitrary decision-making, inadmissibility of retroactivity. However, in some legal systems, the concept of legal certainty is slightly different. These differences also influence the extent and limits of legal certainty as it may not mean total rigidity and prevent necessary changes in statutory laws and decision-making. The reasonable balance is influenced by its axiological content. The article analyses the interpretation practice of the Czech Constitutional Court with the aim to determine the partial values inherent to the principle and categorise them according to their importance. Several partial objectives were determined by qualitative analysis. The quantitative analysis indicates that the key partial objectives include protection of the values comprising a general trust in the law, individuals' legitimate expectations, and a certain degree of predictability of laws, administrative practice and courts' decisions (uniformity, transparency, internal consistency and stability). Having identified these values, further

1 This article was supported by the Student Grant Competition of University of Pardubice SGS_2020_014. 
research may be conducted as to how and to what extent expectations should be upheld.

Keywords: good governance, legal certainty, legitimate expectations, misuse of power, public administration, rule of law

$J E L: K 40, K 38$

\section{Introduction}

All individuals need to be able to plan their future lives, careers, trade and other dealings. Planning ahead with a reasonable degree of certainty what consequences will be induced by a specific action is an essential prerequisite for being autonomous. ${ }^{2}$ This is a generally accepted explanation why expectations created by the legislator, courts and administrative bodies when deciding, providing representations or drafting policies that affect large groups need to be protected (Schønberg, p. 12).

A certain level of constancy of law, court decisions and administrative practice is thus essential and protected by democratic states governed by the rule of law principle; legal certainty being one of the key partial principles of it. However, there needs to be enough room for necessary changes of law and decision-making practice reflecting overriding public interests and societal changes. In recent decades there has been much pressure that the law be more 'flexible' and allow for more extensive discretion due to rapid social, economic and technological change. is There is a risk that excessive flexibility might end in undesirable degree of discretion and a corresponding lack of transparency and accountability (Fenwick, Siems and Wrbka, p. 18). Thus, the interests of individuals regarding their expectations via the state bodies have to be balanced with the interests of larger groups.

The essential legal principles are characterized by a higher degree of generality, stability, permanence, and the impossibility of denying them in statutory laws. All the legal principles when applied need to be balanced and applied in individual cases on the basis of factual circumstances which are found by the court or the administrative authority in detail and with a certainty beyond any reasonable doubts. Moreover, the court or administrative body should be capable of a telelogical interpretation of the legal rule which in case of a legal principle means that they need to understand its nature and the partial val-

2 According to Raz "Autonomy is an ideal of self-creation, or self-authorship; it consists in an agent's successful pursuit of willingly embraced, valuable options, where the agent's activities are not dominated by worries about mere survival. Autonomy in its primary sense is to be understood as the actual living of an autonomous life; autonomy in its secondary sense is to be understood as the capacity to live autonomously. To be autonomous, agents have to meet three conditions: they must possess certain mental capacities, they must have an adequate range of valuable options, and they must enjoy independence from coercion and manipulation. Autonomy should be distinguished from self-realization, as autonomous persons may choose not to realize their capacities. Autonomy itself, in an environment that supports autonomy, is not similarly optional, as living autonomously is the only way of flourishing within an autonomy-supporting environment." (Raz, p. 369) 
ues and objectives it intends to promote. The balancing of principles entails choice of such solution that preserves to the utmost extent the protected values contained in the priciples and the value which is of a higher importance should finally prevail.

It is also true, that these principles reflect values which are to be protected. As the principles are more general and should serve as means of interpretation, guidance for discretion and last resort when the statutory laws keep silent on a specific matter, we may insist that the requirement to reflect values shared in the society is even more pronounced compared to the "ordinary" statutory rules. Gardner explains that: "That we have, in law, a specific social technique for subjecting human conduct to the governance of rules likewise doesn't suggest that subjecting human conduct to the governance of rules is anything more than a technique available to serve some further purpose or purposes (Gardner, p. 207). Presenting 'playing by the rules' as itself the purpose is mistaking the means for the end, a classic legalist mistake. ... the rule of law cannot be interpreted this way (as a matter of everyone's being guided by the law) except at the price of no longer qualifying as a valid moral ideal" (Gardner, p. 213).

The article aims to find these purposes and thus explanation why expectations should be protected through analysis of the partial values protected by the principale of legal certainty. The research being restricted to the Czech law, partial values protected by this principle are examined in the relevant case law of the Czech Constitutional Court. Knowing the most important values should help to open a further discussion and a follow-up research that would explore the question to what extent and under what circumstances the expectations should be protected, i.e. where is the balance between the individuals' interest in constancy of law and the public interest in departures from existing policy that may appear necessary to reflect the social developments. This idea of a follow-up research is supported also in recent literature: "...the role and design of legal certainty is likely to grow in importance in the future. In order to address the variations in the meaning, possibility and desirability of legal certainty, a future research agenda could specifically explore the relationship between legal certainty and other phenomena. To some extent, this issue has always been a concern for the notion of legal certainty, as it is clear that the benefits of legal certainty need to be balanced with the benefits of a law that is sufficiently flexible in order to be respond to changing circumstances. Thus, the relationship between legal certainty and flexibility (or adaptablity) of the law has always been an important one" (Fenwick, Siems and Wrbka, p. 26).

According to Article 1 par. 1 of the Czech Constitution, the Czech Republic is a democratic state governed by the rule of law, founded on respect for the rights and freedoms of man and of citizens. Rule of law is a broad umbrella principle, which encompasses other partial principles (Hoffman, p. 149). The principle of legal certainty comprising protection of legitimate expectations is seen as one aspect of the Rule of law. The precedence of the citizen (fundamental human rights and freedoms) over the state emanates from the rule 
of law principle. Thus, in exercising their powers, public authorities need to recognize these absolute values of the individual. The emphasis on the values of human rights and their protection overcomes the original purely formal understanding of the rule of law based on legalism and positivism and is the cornerstone of the substantive rule of law concept. ${ }^{3}$ Thus, the Rule of law theory in its substantive concept proceeds from human rights protection and the autonomy of individuals (Craig, 1997, p. 95). To be autonomous, it is necessary to foresee actions and plan ahead with some degree of certainty. "The principle of legal certainty is very important. It means that legal measures and legal rules must be clear and consistently applied and that the state action must be sufficiently defined in order to remain predictable. According to the principle of trust, legitimate expectations are protected. If the state has created a specific situation and a person has acted on the reasonable assumption that this situation will remain unchanged, then he or she can rely on that assumption" (Addink, 2019, p. 78).

The requirement of adherence to the principle of legal certainty applies to all branches of state power - the legislative, executive and judicial. First, predictability of applicable statutory laws is an important part of the principle of legal certainty. In order for law to fulfil its regulatory function, citizens affected by legal regulation must have the opportunity to become acquainted with legal norms in advance, to understand them and to understand what the consequences of their misconduct could be. Therefore, it must be properly and officially published, comprehensible, and internally indisputable. At the same time, the law must not have a retroactive effect. The principle of legal certainty means that the legal order is essentially permanent. It may be amended only by legal means and procedures. Moreover, the person affected by legal rules should be able to rely on the legal rules. Thus, he or she must be able to get acquainted with legal requirements in advance and understand what the consequences of his or her behaviour will be. It may be summarised that there is "...the public interest in clear, equal, and foreseeable rules of law which enable those who are subject to them to order their behaviour in such a manner as to avoid legal conflict or to make clear predictions of their chances in litigation" (Neuhaus, p. 795). Barber argues that the legislators should not only produce stable and prospective laws, they must also "...consider the ability of the citizens to understand and make use of the rules" (Barber, p. 485). Thus, he argues, there is a social dimension in the rule of law concept demanding easy and cheap access to courts and state funded education. Uneducated people can not exercise their rights as they do not know, what these are. "A

3 Gardner explains further that "The word 'substantive' has to be put in front of 'aims of legal rules' only as a way of alerting us to the fact that the means-end distinction is another one with a shifting baseline. All means are capable of serving as subsidiary ends, as intermediate destinations on the way to our destination. That the law lives up to its internal morality may, of course, be treated as a subsidiary end, and in that sense an ideal for law. But Fuller is warning us (again) not to fall into the legalistic trap, not to mistake the subsidiary end for the end to which it is subsidiary, not to think that we need have no aims for legal systems other than that they conform to the rule of law. Law's inner morality is only the morality of how, not the morality of why. If there were no external morality applicable to law we wouldn't have anything worthwhile to do with law in the first place and there wouldn't be any intelligible role for an internal morality of law" (Gardner, p. 206). 
legal system requires some level of material well/baing if the purported laws are to prove effective" (Barber, p. 483).

Further, the requirement of legitimate expectations, which affects the decision-making of administrative bodies and courts, whose decisions should be, in principle, foreseeable and at the same time ensure equal access to litigants, must be met. In administrative law the importance of certainty is increased due to discretionary powers vested in public authorities. Individuals cannot easily predict how these discretionary powers will be exercised because of indeterminate language of laws and informal working rules and other constraints (Schønberg, p. 13). Czech law enshrines explicitly the binding nature of the principle of legal certainty in administrative proceedings in Sec. 2 par. 4 of the Act No. 500/2004 Sb., Code of Administrative Procedure, as amended, which stipulates that: "An administrative authority shall care to ensure that the adopted solution be consistent with the public interest and that it respected the circumstances of the particular case and that no reasonable discrepancies arose in respect of decisions on cases of identical or similar merit." Legitimate expectations are stressed. The Supreme Administrative Court elaborates the principle in detail in its case law stressing the fact that administrative bodies are bound by their own established administrative practice, consistent interpretation of procedural and substantive legal rules, publicly declared policy within the limits of administrative discretion, an internal interpretation or application directive, and the binding nature of a specific and qualified assurance on a right or procedural practice provided by the administrative body to the addressee. ${ }^{4}$

There are many influences that have combined into the requirement of certainty and predictability. They are among others the practical interest in peace and quiet, economic interests (conservatism, protection of vested interests), devotion to custom and also such which are not certainly not praiseworthy as judicial abhorrence of responsibility (the same applies to administrative decision-making) (Wade, p. 195). Further partial values and goals may be identified such as fairness in public administration, reliance and trust in government, equality, and autonomy connected to the ability to plan one's life (Сraig, 2012, pp. 680-681). According to legal theory, all these partial principles may be considered as sub-principles of the principle of legal certainty. However, they may differ in individual legal systems, as the precise content of the principle varies (Craig, 2012, p. 679). This article analyses the practice of the Czech Constitutional Court (hereinafter also only the "CC") and its relevant case law with the aim to determine the partial objectives of the principle of legal certainty in the Czech legal system and categorise them according to the importance attributed to them by the CC.

4 Most recently, the Supreme administrative court links legal certainty and protection of legitimate expectations in administrative decision-making this way e.g. in its judgment No. 9 As 65/2020 of 12 May 2020. 


\section{Methods}

As other key priciples of law the principle of legal certainty comprises an axiological quality which influences interpretation of legal rules and application of statutory laws. To find this axiological quality, the values inherent to the principle, and the exact purport of thereof, we will follow up on the qualitative analysis of the case law of the CC. The purpose of this analysis is to determine how the CC interprets this principle in its decisions, i.e. what are the main values deemed to be protected by insisting on application of this principle by all branches of the state power. Thus, the main research question is what values are meant to be protected by the principle of legal certainty as one of the key sub-principles of the rule of law according to theinterpretation of the CC, and whether any of these values are of a higher importance. The hypothesis grounded on the literature research mentioned above is that there will be several objectives and values including predictability, protection of legitimate expectations, and prevention of arbitrary decision-making. The second hypothesis is that we will find further partial values.

First, qualitative research of relevant decisions related to the principle of legal certainty was carried out in order to identify the key partial principles and protected values. Several different methods were applied as relevant. First, a comprehensive overview of the principle of legal certainty was performed through literature review and using normative-analytical method. With systematic approach, the authors analysed relevant case law of the Czech CC providing interpretation of statutory law rules and legal argumentation using this principle. The sample of the decisions was studied using analogy, comparative method and inductive reasoning. Finally, a synthesis of the findings was carried out, depicting the most common partial values repeatedly occurring in the studied case law.

Further, quantitative analysis followeds to ascertain which of the partial values found in the qualitative analysis repeat more often and thus may be identified as the most crucial and more important. In the quantitative analysis the authors examined a selected sample of 20 judgments of the CC, which should clearly outline how the CC views the axiological content of principle of legal certainty and how it treats it in its decision-making practice from 1995 to the present time. The examined sample of decisions was selected applying a combination of three following criteria. First, a larger sample of the case law of the CC was provided through the NALUS ${ }^{5}$ database for searching the case law of the CC for a decisive twenty-five-year period. The first criterion for the selection of the case law in the electronic database was the occurrence of the principle of legal certainty (and its sub-principles) in the subject matter of the proceedings. Hereby, about 400 decisions were selected. Further precising criterion was the significance of these cases, which was ascertained through the level of their further citation in more recent CC case law. The cases that were cited later most frequently were chosen for the quantitative analysis.

5 NALUS is a database of the Constitutional Court's decisions enabling search by key words available at https://nalus.usoud.cz. 
We assume that the more often the legal sentence used in a previous case is cited in later cases of the same judicial body which are therefore based on such prejudicature, the more accurate and important the judges find the previous case which they later cite.Therefore, the case law that may be considered as ground-breaking was chosen, as in the area of the CC's findings and interpretation of the principle of legal certainty, this case law can be considered permanent and relatively strict. This sample of 15 judgements determined by the second criterion was accompanied by further 5 more recent decisions dating from 2015 to 2019 produced by the qualitative analysis as crucial and proving that the approach of the $\mathrm{CC}$ to the given principle has not changed fundamentally recently. We have decided to add these 5 cases as the most recent decisions could not meet the requirement of numerous further citations because of the lack of furthr newer decissions. In the conclusion the authors compare the findings from both their qualitative and quantitative analysis with the doctrine determined in the literature review above.

\section{Results}

The values of predictability of law, constant application practice and thus protection of legitimate expectations of individuals and legal persons as described above should be adhered to by all the three branches of state power. Therefore, the qualitative analysis contains CC's decisions relevant to the legislature, the executive power represented by administrative bodies and last but not least the courts. The key decisions are further divided into three categories, in order not to overlook any partial value that could potentially concern (or be of the utmost importance for) only one of the branches of power.

\subsection{Legally Binding Rules}

The Constitutional Court constantly finds that the principles of predictability of law and legitimate expectations are inextricably linked to the principle of legal certainty. In the most general sense the Court summarized the substantial core requirement as follows: "The obligations and promises that the state makes to individuals should be kept (principle of legitimate expectations)" (Judgment of the Constitutional Court file no. Pl. ÚS 12/14 of 16 June 2015). Thus, aanyone who follows valid law and relies on it should not be refuted from his expectations. An interpretation of the protection of citizens' trust in the law can be found, for example, in the judgment of the Constitutional Court in file No. I.ÚS 520/06 of 23 January 2008 as follows: "The nature of the material rule of law then also radiates the maximum associated with it, according to which, if someone acts in (legitimate) trust in any Act (or in legal rules in general), he should not be disappointed in this trust."

The issue of riders ${ }^{6}$ is one of the areas covered mostly by the case law concerning principle of legal certainty in the field of legislature. Riders might

6 A rider is an amendment to the bill, which is currently being discussed in parliament, with little connection to the subject-matter of the discussed bill. Legislators sometimes seize the opportunity to further their political agendas as a rider not always related to the subject mat- 
be breaching the principle of legitimate expectations fundamentally when the legislators approve provisions that have no or little connection with the content of the bill. Often, were these proposed amendments discussed separately, they would probably not be accepted. In connection with their controversy, the CC in its decision file no. Pl. ÚS 77/06 of 15 February 2007 declared riders to be in breach with the Constitution. The Constitutional Court argued that: "The requirement of predictability of a law as part of the rule of law ceases to be fulfilled when an amendment to a law is part of another law in a formal sense, the content of which has nothing to do with the amended law. Orientation of the addressee of a legal norm in the legal system becomes completely impossible without the use of information technology devices... At the same time, it is clear that without the possibility of using these systems, it is no longer possible to learn the legal system of the Czech Republic. Thus, the application of the general legal principle, according to which ignorance of the law does not excuse anyone becomes rather problematic. Therefore, the statutory laws become completely unpredictable for their addressees. Although the mentioned principle is a necessary condition for the effectiveness of any system of valid law, it cannot be interpreted only to the detriment of the addressees of the law, but also as a duty of public power to make the law recognizable."

The inadmissibility of the retroactive effect of legal norms is another important value protected by the principle of legal certainty. The CC in its key decision file no. IV. ÚS 215/94 of 8 June 1995 emphasized that: "Part of the legal certainty is also the prohibition of retroactivity of legal norms, their retroactive interpretation... Therefore, if someone acts in trust in a law, he should not be disappointed in that trust." Further, in its decision file no. Pl. ÚS 33/01 of 12 March 2002, the CC explained the reasons of inadmissibility of retroactivity as follows: "The emphasis placed on the prohibition of retroactive effect of legal norms as one of the basic elements of the rule of law stems from the requirement of legal certainty. The prohibition of retroactivity consists in the fact that, according to the current legal norm, it is in principle not possible to assess human behavior, legal facts or legal relationships that took place before the legal norm came into force. The prohibition of retroactive effect of legal rules is based on the principle that everyone must be able to know which conduct is prohibited in order to be held liable for breaches of the prohibition."

Legal theory and practice distinguish between true and false retroactivity. The essence of true retroactive effect is that according to a certain current legal norm, it is possible to assess legal facts or legal relationships that took place before the legal norm came into force, i.e. that the new legal norm may change the legal consequences which, according to the law, occurred before the date of its entry into force. For false retroactivity, legal relationships established under the old law are governed by that law until the new law comes

ter of the bill. A rider may be attached to a bill in an attempt to sneak through a measure that would not attract majority support proposed by itself. Sometimes, too, a bill's opponents may attempt to defeat it by adding a controversial rider. 
into force, but then governed by that new law. "Creation of a legal relationship existing before the entry into force of the new legislation is governed by the original legislation. However, the legal claims arising from such relationship are governed by the original legislation only until it is repealed. Since then they are governed by the new legal rules. In general, in cases of conflict between the old and the new legal norm, false retroactivity will be used" (Decision of the Constitutional Court file no. Pl. ús 33/01 of 12 March 2002).

Exceptions from the general rule prohibiting retroactivity, are not rare (Constitutional Court decision file no. Pl. ÚS 21/96 of 4 February 1997). While true retroactivity is generally considered to be inacceptable, false retroactivity is generally tolerated. There are exceptions from both eventualities ${ }^{7}$. However, the prohibition of retroactivity can be waived only in exceptional cases, and only by a positive provision. In its decision file no. III. ÚS 3221/11 of 12 December 2013 the CC found that there is a difference between the exercise of power by the legislator and the judiciary: "The given rule applies in principle to every act of public power, i.e. also to acts of legislative and judicial power. Still, the question arises whether the rules, which apply in relation to the activity of the legislator, can be applied to a judicial finding of law. This question should be answered in the negative for the following reasons. The legislator consists of generally valid, inter omnes and forward-looking rules, which are officially published and have a clearly defined validity and effectiveness. The duty of the legislator is to address whether and how to protect the addressee's confidence in the previous legal situation... Still, a judicial finding of a law cannot (usually) be considered as drafting legislation, but (only) as its interpretation and clarification, with inter partes effects, especially then, by its very nature, this seems "retroactive", as the court assesses (usually) the conduct that has taken place in the past. Justice, as a "finding" institution, therefore interprets the law (within its limits), which applies "from the beginning" and usually finds its application (as a law in the material sense) in other cases, the factual basis of which also lies in the past..." However, if the courts adopt an interpretation which is retroactive in the form of true retroactivity, they violate the principles of legal certainty and the citizen's trust in the law, which are integral parts of the attributes of the rule of law (Constitutional Court decision file no. I. ÚS 344/04 of 15 December 2004).

7 In its recent decision of file no. Pl. Ús 5/19 of 1 October 2019 the Constitutional Court found false retroactivity in breach of the principle of legitimate expectations in the case of additional taxation of church restitutions It was agreed in the agreements based on statutory stipulations and signed by the government and individual churches that the financial compensation in the amount stipulated by law and in the contract (valorized) will be paid in thirty annual installments, and that the once-established legal right to the payment of the full financial compensation does not entitle the future legislator to unilaterally reduce it in any way. The Court summarized that: "By the contested legislation, the legislator ... decided on the de facto reduction of financial compensation, the full amount of which gave rise to legal rights and legitimate expectations for churches and religious societies at the time of concluding settlement agreements. The additional reduction in financial compensation for the injustices caused by the criminal communist regime goes against the basic principles of the democratic rule of law. 


\subsection{Administrative Bodies Application Practice}

However, the principle of legal certainty in the sense of the necessary predictability of the consequences of a legal regulation and claims to its certainty and comprehensibility cannot be limited to the text of the legal regulation itself. ${ }^{8}$ Subsequent interpretation by an administrative body or in court decision-making, ${ }^{9}$ leads to a further completion of the legal rule. This further completion of a legal rule requires that the administrative bodies accompany their decisions with due reasoning, with a clear explanation of interpretative methods used.

The predictability of the outcome of administrative procedure co-guarantees legal certainty and ensures general confidence in the law. ${ }^{10}$ Foreseeable behaviour of administrative bodies in accordance with effective statutory laws also excludes possible arbitrariness. "The principle of legal certainty must then be combined with the prohibition of arbitrary decisions, so that the discretion of public authorities is limited by procedures to prevent abuse of that discretion..." (Decision of the Constitutional Court file no. Pl. ÚS 12/14 of 16 June 2015). Further, only well-reasoned decisions limit the scope for possible arbitrariness and ensure a similar assessment of similar cases. "This requirement is all the more urgent in a situation where the legislation on the basis of which a decision is made is made up of only very general principles" (Decision of the Constitutional Court file no. II. ÚS 482/18 of 28 Nov. 2018).

Legitimate expectations of an individual must be understood as the expectations of a certain action of public authorities, which will correspond to the clear content of the legal order. Predictability of law is perceived as a precondition for self-determination of each individual who chooses his own destiny. Thus, each individual must be ensured protection of his expectations and protection of confidence in predictability of law (Decision of the Constitutional Court file no. III.ÚS 3221/11 of 12 December, 2013). Predictability is also important for the planning of business activities and influences economic outcome, as the recent pandemic situation has clearly revealed. "Public administration, however, should be the guarantor of even non-economic values, especially essential democratic and human values and also sustainability" (Fuka, 2018).

Moreover, it is not only the expectations pro futuro positive action of administrative bodies but also the expectations, that the administrative body will not take any action at all and the individual will be left to enjoy his already gained

8 "The requirement of legal certainty affects both the creation of law (the question of stability of law and legality of its creation) and the application of law" (Constitutional Court decision file no. I. ÚS 420/09 of 3 June 2009).

9 "Stability of the legal order and legal certainty are influenced not only by the legislative activity of the state (creation of law), but also by the activities of state bodies applying law, because only the application and interpretation of legal norms creates public awareness of what is and what is not law" (Decision of the Constitutional Court file no. II. ÚS 1851/19 of 16 August 2019).

10 "The principle of predictability of law, as an important attribute of the rule of law, is essentially related to the principle of legal certainty and is a necessary prerequisite for the general trust of citizens in law..." (Decision of the Constitutional Court of the Czech Republic file no. IV. ÚS 610/06 of 22 June, 2009). 
rights. Thus, further aspect of legal certainty is the protection of rights gained in good faith. In the decision of the CC file no. III.ÚS 705/06 of 14 February 2008, explains that: "The protection of conduct committed in confidence in the law presupposes that the legal or natural person acts in confidence not only in the text of the relevant legislation, but in particular also in the continuous interpretation of such a regulation by public authorities, including the practice of administrative authorities and the interpretation of law by administrative courts. Such already completely constant administrative practice... and any subsequent decisions of administrative courts (...) and the interpretation contained therein form, in a material sense, part of the relevant interpreted legal norm, from which the protection of the addressees of legal norms in law derives."

In many cases, inactivity can have positive effects for the addresses of public administration, both in terms of a lack of punishment of the perpetrator of a minor offence, as well as the acquisition of the belief that the public administration will tolerate or put up with a certain situation" (Skulová, p. 48).

Any individual, guided by trust in the law, should always have at least a general idea of whether his or her behaviour is a legally permissible or prohibited act. Nevertheless, reassessment of the interpretation by administrative authorities in the unchanged state of the interpreted legal regulations is not absolutely forbidden. Still, it may cause a serious interference with legal certainty. Intensity of this intervention must always be assessed in the light of the specific situation. "However, a change in long-term administrative practice or case law, but in the unchanged state of the law, can only occur for serious reasons aimed at achieving a certain legally protected value; in no case, however, may this be done arbitrarily" (Decision of the Constitutional Court file no. IV. ÚS 610/06 of 22 June 2009).

\subsection{Courts' Decisions and Stare Decisis Doctrine}

The constant application of laws does not concern only public administration. The courts are bound by the same requirements regardless of whether the court decision-making has or does not have a precedent character. "The principles of legal certainty and predictability of a court decision entitle a party to the proceedings to assume that the court knows the law and that it will interpret unambiguous provisions of generally binding regulations in accordance with their unambiguity" (Decision of the Constitutional Court file no. II ús 3764/12 of 13 May 2014). All courts must interpret and apply a binding provision of the law so that the legal opinion expressed by the higher court is respected. Thus, the court must do so in a way that is in harmony with the binding legal opinion of the superior court but also foreseeable for the participants in the proceedings in the light of its own legal conclusions already outspoken in the same case (Decision of the Constitutional Court file no. II. Ús 296/01 of 26 November 2002). However, the principle of predictability of law and its interpretation does not apply only to the lower courts, on the contrary 
it applies to the entire judicial system (Decision of the Constitutional Court's file no. II. ÚS 4029/19 of 18 March 2020).

The CC expressed the reasons for stare decisis doctrine succinctly in its decision file no. II. ÚS 1851/19 of 16 August 2019, "... different decision-making practice of courts on identical matters is fundamentally undesirable [...], because the substantive rule of law is built, among other things, on citizens' trust in the law and the rule of law." Therefore, theoretically if a person claimed his rights in court in a case similar to one ruled in favour of another person, he/ she should not be treated differently. If not, it would certainly indicate a volatile interpretation of legal norms and thus could also jeopardize the perception of the principle of legal certainty and predictability of law (Decision of the Constitutional Court file no. No. I ÚS 566/07 of 5 August 2009).

Generally, in relation to the binding nature of judicial case law, an interpretation once already made, should constitute a starting point for deciding on the following cases of the same kind, from the point of view of the principles of legal certainty, predictability of law, protection of legitimate expectations in law (legitimate expectations) and the principle of formal justice. Changes in the case law of the courts are therefore acceptable only as a consequence of natural and gradual development in society, to which the judiciary must respond. "However, a change in judicial decision-making practice, especially in the case of a supreme court called upon to unify the case law of lower courts, must be approached with caution and in the assessment of individual cases so as not to violate the above principle of predictability of judicial decisionmaking and denied the requirement for a fair decision in the sense of respect for the fundamental rights of the participants in the proceedings" (Decision of the Constitutional Court file no. II. ÚS 76/17 of 3 April 2018). It is further elaborated in the decision file no. II. ÚS 1851/19 of 16 August 2019 that "The principle of legal certainty and also the principle of equality before the law require that the case law of courts change under certain conditions (change of values protected by the law, change of the societal cultural picture of the law, changes in the structure of the legal order or changes in those components of the legal order which are in the hierarchy of legal norms superior to the interpreted norm, etc.), by a certain predetermined procedure." A change in the interpretation thus might be justified only by sufficient relevant reasons substantiated by rational and more convincing arguments subsequently found, in summary better corresponding to the legal order.

\section{Discussion}

It follows from the above qualitative analysis, that the principle of legal certainty including its sub-principles is considered not only by doctrine but also by the CC to be one of the most important partial principles of the rule of law. It is essential to observe this principle not only when drafting bills, but also during the application procedure including the interpretation by administrative bodies and courts. As the result of the above-described qualitative analysis, we were able to distinguish the following repeating partial values (or 
perhaps partial objectives) pursued by the principle of legal certainty according to the CC:

- Formal justice of the legal order and fair procedure carried out by administrative bodies according to the effective laws,

- General trust in the law and the legitimate expectations of individuals,

- Certain degree of predictability of laws, administrative practice and courts' decisions (incl. uniformity, transparency, internal consistency and stability),

- Exclusion of misuse of state power and illegal conduct of public authorities

- Inadmissibility of retroactivity and retroactive interpretation of legal norms (including exceptions)

- Рroper formal value of laws

- Prevention of and subsequent protection against arbitrary decision-making

- Certain framework of conditions for changes in case law.

In order to determine which of the partial objectives the CC considers to be the most important, frequency of their appearance in the already used sample of 20 decisions was analysed. The decisions аге numbered according to the date of their issuance. 
Jana Janderová, Petra Hubálková

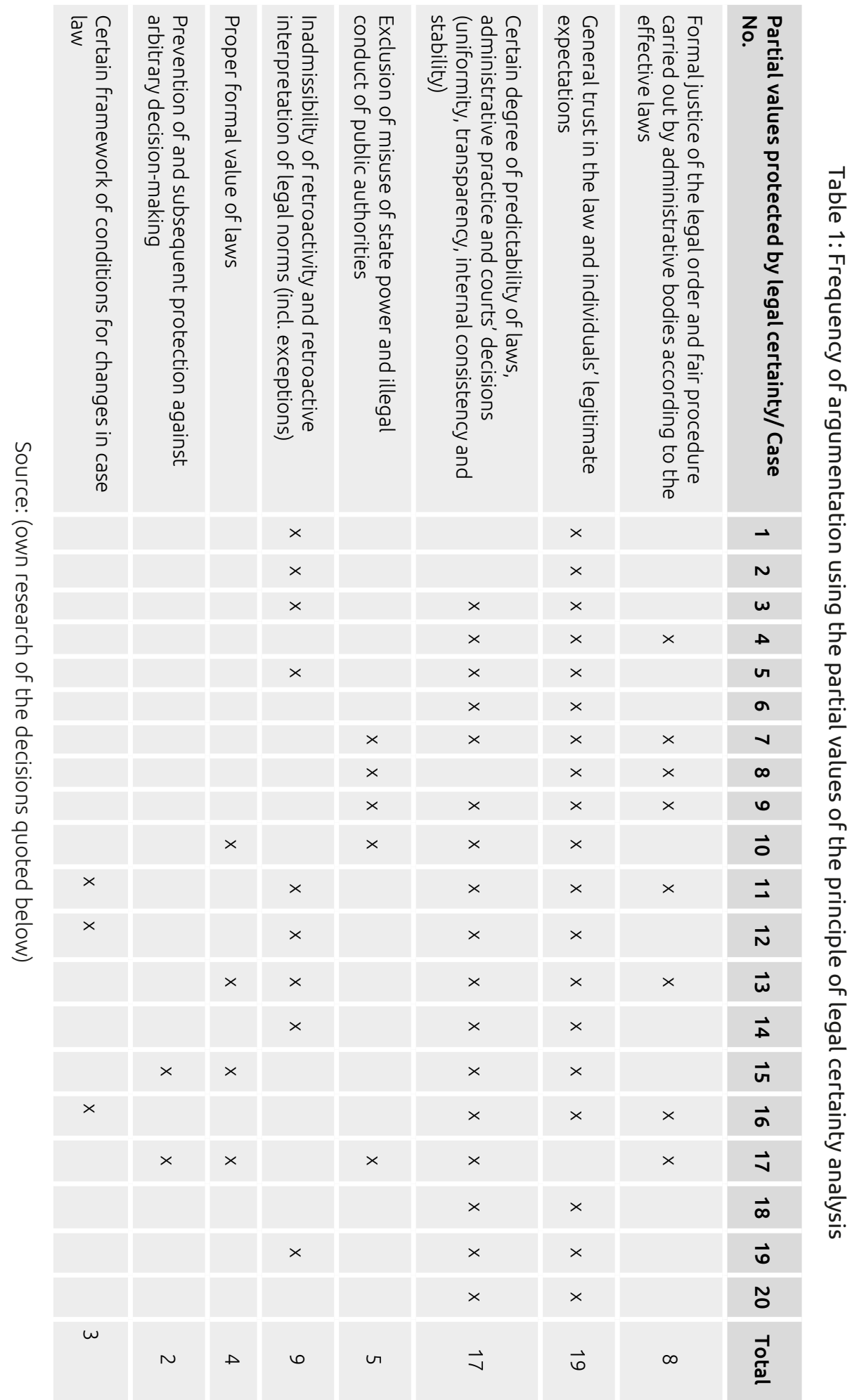

76 Central European Public Administration Review, Vol. 19, No. 1/2021 
The following sample of the Constitutional Court's case law was used in the analysis:

1 Decision of the Constitutional Court of the Czech Republic file no. IV. ÚS 215/94 of June 8th, 1995.

2 Decision of the Constitutional Court of the Czech Republic file no. Pl. ÚS 21/96 of February 4th, 1997.

3 Decision of the Constitutional Court of the Czech Republic file no. Pl. ÚS 33/01 of March 12th, 2002.

4 Decision of the Constitutional Court of the Czech Republic file no. II. ÚS 296/01 of November 26th, 2002.

5 Decision of the Constitutional Court of the Czech Republic file no. I. ÚS 344/04 of December 15th, 2004.

6 Decision of the Constitutional Court of the Czech Republic file no. Pl. ÚS 77/06 of February 15th, 2007.

7 Decision of the Constitutional Court of the Czech Republic file no. I. ÚS 520/06 of January 23rd, 2008.

8 Decision of the Constitutional Court of the Czech Republic file no. III. ÚS 705/06 of February 14th, 2008.

9 Decision of the Constitutional Court of the Czech Republic file no. I. ÚS 420/09 of June 3rd, 2009.

10 Decision of the Constitutional Court of the Czech Republic file no. IV. ÚS 610/06 of June 22nd, 2009.

11 Decision of the Constitutional Court of the Czech Republic file no. I. ÚS 566/07 of August 5th, 2009.

12 Decision of the Constitutional Court of the Czech Republic file no. III.ÚS 3221/11 of December 12th, 2013.

13 Decision of the Constitutional Court of the Czech Republic file no. II. ÚS 3764/12 of May 13th, 2014.

14 Decision of the Constitutional Court of the Czech Republic file no. Pl. ÚS 1/14 of March 31st, 2015.

15 Decision of the Constitutional Court of the Czech Republic file no. Pl. ÚS 12/14 of June 16th, 2015.

16 Decision of the Constitutional Court of the Czech Republic file no. II. ÚS 76/17 of April 3rd, 2018.

17 Decision of the Constitutional Court of the Czech Republic file no. II. ÚS 482/18 of November 28th, 2018.

18 Decision of the Constitutional Court of the Czech Republic file no. II. ÚS 1851/19 of August 16th, 2019.

19 Decision of the Constitutional Court of the Czech Republic file no. Pl. ÚS 5/19 of October 1st, 2019.

20 Decision of the Constitutional Court of the Czech Republic file no. II. ÚS 4029/19 of March 18th, 2020. 
The table above shows that in the examined sample of case law the CC argued by the requirement of general trust in the law and legitimate expectations as the most important partial goal of the principle of legal certainty in 19 cases. Thus, this partial value is seen to be of utmost importance. This finding supports the fact that the doctrine often uses legitimate expectations and legal certainty in the same meaning. Further, in 17 cases, the CC emphasizes the principle of predictability of law, administrative and judicial decision-making practice which contains the requirement for their uniformity, transparency, internal indisputability and stability. The inadmissibility of retroactivity and retroactive interpretation of legal norms (including exceptions to the contained rules) was stated by the Constitutional Court as the partial objective of the principle of legal certainty in 9 cases. In 8 cases, the CC assigned to the principle of legal certainty the need for formal justice of the legal order and fair procedure of administrative bodies according to valid legislation.

The following partial objectives pursued in the principle of legal certainty were stressed by the CC the least - to exclude possible misuse of state power and unlawful conduct of public authorities (in 5 cases), the proper formal value of a law (in 4 cases), ensuring a certain framework for changes in case law (in 3 cases) and the aim of prevention and subsequent protection against arbitration (in 2 cases). We believe that in case of the misuse of power it is because of the close relationship of the principle of legality and principle of legal certainty in this particular value. The principle of legality is stressed by the CC as the key aspect of rule of law, and misuse of power is closely intertwined with it. Thus, mentioning it also together with legal certainty is not necessary, however doing so, the CC only underlines its importance. The last three partial objectives, on the other hand, seem to be supplementary to the main protected values described above as they concern only specific cases. We may summarise, that both hypotheses set in part 2 of the article proved to be correct.

\section{Conclusion}

The adherence of the state power to the principle of legal certainty is a characteristic sign of the rule of law. Its fundamental attribute should be such an arrangement of public affairs in which everyone can have confidence in the law and is able to predict the consequences of his or her behaviour. The partial principles and protected values are several and they may vary depending on the legal system. Determining them may serve as a starting point for further research of legal certainty limits as the law and decision/making practise need to reflect societal changes and may not be rigid under all circumstances. Legal principles are characterized by a higher degree of generality, stability, permanence, and the impossibility of denying them in statutory laws. Thus, the legislator needs to adhere to the essential legal principles so that the legal order stays consistent in its axiological and teleological content. The courts and administrative bodies have to apply legal principles when deciding individual cases with a knowledge of their nature and the partial values and objectives they promote. The balancing of principles entails choice of such solution that 
preserves to the utmost extent the protected values contained in the principles and the value which is of a higher importance should finally prevail.

Qualitative analysis of the principle of legal certainty was performed, to understand the essence of this principle and the sub-principles belonging to it. A selected sample of the case law of the CC for the previous twenty-five-year period was used. This analysis clearly outlined how the CC treats this principle in its case law and what partial objectives it pursues with the principle of legal certainty. Subsequently, a quantitative analysis of the frequency of use of partial objectives in a narrower sample of twenty cases was performed. This analysis has shown that the CC considers the most important partial objectives of the principle of legal certainty to be the requirement of general public confidence in the law and the requirement of legitimate expectations which affects the activities not only of the legislator but also of administrative bodies and courts, whose decisions should be, in principle, foreseeable and at the same time ensure equal access to all participants to the proceedings. However, there are further values such as formal justice of the legal order and fair procedure carried out by administrative bodies, prevention of and subsequent protection against arbitrary decision-making, and which all are closely intertwined and show the importance of the principle in administrative decision-making. These values correspond with those found by the literature review, however they reflect specific Czech legal environment. Determining these values may prompt further research of the balance between the principles of legal certainty and legality, as necessary changes in administrative policies must not be unduly fettered. 


\section{References}

Addink, H. (2019). Good Governance Concept and Content. Oxford: Oxford university press, p. 352.

Berger, T. and Lake, M. (2018). Human Rights, the Rule of Law, and Democracy. In A. Draude, T. A. Börzel, and T. Risse, eds., The Oxford Handbook of Governance and Limited Statehood. Oxford: Oxford University Press, pp. 416-437.

Barak, A. (2010). Proportionality and Principled Balancing. Law \& Ethics of Human Rights, 4(1), pp. 1-16. DOI 10.2202/1938-2545.1041

Barber, N. (2004). Must Legalistic Conceptions of the Rule of Law Have a Social Dimension? Ratio luris, 17(4), pp. 474-488. DOI 10.1111/j.14679337.2004.00278.x

Bingham, T. (2011). The Rule of Law. London: Penguin Books, p 224.

Brown, A. (2011). Justifying Compensation for Frustrated Legitimate Expectations. Law and Philosophy, 30(6), pp. 699-728. DOl: 10.1007/sl0982011-9108-Z

Brown, A. (2012). Rawls, Buchanan, and the Legal Doctrine of Legitimate Expectations. Social Theory and Practice, 38(4), pp. 617-644. DOI: 78.128.158.111

Carlin, R. E. (2012). Rule-of-Law Typologies in Contemporary Societies. Justice System Journal, 33(2), pp. 154-173.

Carlin, R. E. and Sarsfield R. (2012). Rethinking the Rule of Law: Concepts, Measures, and Theory. Justice System Journal, 33(2), pp. 125-130.

Clayton, R. (2003). Legitimate Expectations, Policy, and the Principle of Consistency. The Cambridge law Journal, 62(1), pp. 93-105.

Craig, P. (1997). Formal and Substantive Conceptions of the Rule of Law: An Analytical Framework. Public Law, pp. 467-487. DOI:10.4324/9781315085302-4

Craig, P. (2012). Administrative Law. Seventh Edition. London: Sweet \& Maxwell, p. 980.

Craig, P. (2015). UK, EU and Global Administrative Law. Foundations and Challenges. Cambridge: Cambridge University Press, p. 830.

D’Amato A. (1983). Legal Uncertainty. California Law Review, 71(1), pp. 1-55.

Decision of the Constitutional Court of the Czech Republic file no. IV. ÚS 215/94 of June 8th, 1995.

Decision of the Constitutional Court of the Czech Republic file no. Pl. ÚS 21/96 of February 4th, 1997.

Decision of the Constitutional Court of the Czech Republic file no. Pl. ÚS 33/01 of March 12th, 2002.

Decision of the Constitutional Court of the Czech Republic file no. II. Ús 296/01 of November 26th, 2002.

Decision of the Constitutional Court of the Czech Republic file no. I. ÚS 344/04 of December 15th, 2004.

Decision of the Constitutional Court of the Czech Republic file no. Pl. ÚS 77/06 of February 15th, 2007.

Decision of the Constitutional Court of the Czech Republic file no. I. ÚS 520/06 of January 23rd, 2008. 
Decision of the Constitutional Court of the Czech Republic file no. III. ÚS 705/06 of February 14th, 2008.

Decision of the Constitutional Court of the Czech Republic file no. I. ÚS 420/09 of June 3rd, 2009.

Decision of the Constitutional Court of the Czech Republic file no. IV. ÚS 610/06 of June 22nd, 2009.

Decision of the Constitutional Court of the Czech Republic file no. I. ÚS 566/07 of August 5th, 2009.

Decision of the Constitutional Court of the Czech Republic file no. III.ÚS 3221/11 of December 12th, 2013.

Decision of the Constitutional Court of the Czech Republic file no. II. ÚS 3764/12 of May 13th, 2014.

Decision of the Constitutional Court of the Czech Republic file no. Pl. ÚS 1/14 of March 31st, 2015.

Decision of the Constitutional Court of the Czech Republic file no. Pl. ÚS 12/14 of June 16th, 2015.

Decision of the Constitutional Court of the Czech Republic file no. II. ÚS 76/17 of April 3rd, 2018.

Decision of the Constitutional Court of the Czech Republic file no. II. ÚS 482/18 of November 28th, 2018.

Decision of the Constitutional Court of the Czech Republic file no. II. ÚS 1851/19 of August 16th, 2019.

Decision of the Constitutional Court of the Czech Republic file no. Pl. Ús 5/19 of October 1st, 2019.

Decision of the Constitutional Court of the Czech Republic file no. II. ÚS 4029/19 of March 18th, 2020.

Decision of the Supreme administrative court file No. 9 As 65/2020 of May 12th, 2020.

Dicey, A. (1982). Introduction to the Study of the Law of the Constitution. Indianapolis: Liberty Fund Inc., p. 585.

Ehrlich, I. and Posner, R. A. (1974). An Economic Analysis of Legal Rulemaking. The Journal of Legal Studies, 3(1), pp. 257-286.

Eyer, K. R. (2008). Administrative adjudication and the rule of law. Administrative Law Review, 60 (3), pp. 647- 706.

Fenwick, M., Siems, M. and Wrbka, S. (2017). The State of Art and Shifting Meaning of Legal Certainty. In M. Fenwick., M., Siems and S. Wrbka, eds. The Shifting Meaning of Legal Certainty in Comparative and Transnational Law. Oxford: Hart publishing, pp. 1-26.

Fuka, J., Lešáková, P. and Bat́a, R. (2018). Sustainable Value as a Tool for Performance Measurement of the Region. Lex localis - Journal of Local SelfGovernment, 16(4), pp. 693-713. DOI: 10.4335/16.4.693-713(2018)

Gardner, J. (2012). The Supposed Formality of the Rule of Law. In J. Gardner, ed., Law as a Leap of Faith: Essays on Law in General. Oxford University Press, pp. $195-221$.

Hofmann, H., Rowe, G. and Turk, A. (2013). Administrative Law and Policy of the European Union. Oxford: Oxford University Press, reprint, p. 977.

Hoffmaster, B. (1982). Understanding Judicial Discretion. Law and Philosophy, 1(1), pp. 21-55. 
Holländer, P. (2012). Filosofie práva. 2., rozš. vyd. Plzeň: Vydavatelství a nakladatelství Aleš Čeněk, p. 424.

Janderová, J. (2019). Impact of the Rule of Law as a Fundamental Public Governance Principle on Administrative Law Interpretation in the Czech Republic. Central European Public Administration Review, 17(2), pp. 117-139. DOI: 10.17573/сераr.2019.2.06

Klatt, M. (2007). Contemporary Legal Philosophy in Germany. Archiv für Rechtsund Sozialphilosophie /Archives for Philosophy of Law and Social Philosophy, 93(4), pp. 519-539.

Neuhaus, P. H. (1963). Legal Certainty versus Equity in the Conflict of Laws Law and Contemporary Problems. New Trends in the Conflict of Laws, 28(4), pp. 795-807.

Portuese, A. et al. (2017). The principle of legal certainty as a principle of economic efficiency. European Journal of Law and Economics, 44(1), pp. 131-156.

Raz, J. (1986). Morality of Freedom. Oxford: Oxford University Press, p. 436.

Salevao, I. (2005). Rule of Law, Legitimate Governance \& Development in the Pacific. ANU Press, p. 207.

Shaw, G. (2013). H. L. A. HART'S Lost Essay: "Discretion" and the Legal Process School. Harvard Law Review, 127(2), pp. 666-727.

Skulová, S. and Bražina, R. (2018). New approaches to the right to be heard in relation to the application of alternatives to administrative sanctions. Central European Public Administration Review, 16(1), pp. 161-178. Retrieved from http://cepar.fu.uni-lj.si/index.php/CEPAR/article/view/363.

Stefan, O. (2012). European Union Soft Law: New Developments Concerning the Divide Between Legally Binding Force and Legal Effects. The Modern Law Review, 75(5), pp. 879-893.

Tamanaha, B. (2004). On the Rule of Law: History, Politics, Theory. Cambridge: Cambridge University Press. p. 190.

Tomoszek, M. (2016). Podstatné náležitosti demokratického právního státu. Praha: Leges, p. 192.

Tremblay, L. B. (2003). General Legitimacy of Judicial Review and the Fundamental Basis of Constitutional Law. Oxford Journal of Legal Studies, 23(4), pp. 525-562.

Van Caenegem, R. (1991). Legal history: A European perspective. London; Rio Grande: The Hambledon Press, p. 242.

Wade, H.W.R. (1941). The Concept of Legal Certainty A Preliminary Skirmish. The Modern Law Review, 4(3), pp. 183-199.

Williams, A. T. (2009). Taking Values Seriously: Towards a Philosophy of EU Law. Oxford Journal of Legal Studies, 29(3), pp. 549-577. 